ARTIGO

\title{
EDUCAÇÃO E VALORES HUMANOS: UMA APRECIAÇÃO DOS ESTUDOS PRODUZIDOS NO BRASIL NOS ANOS 2013 a 2018
}

\author{
LIVIA SOUSA DA SILVA ${ }^{1}$ \\ ORCID: https://orcid.org/0000-0002-1652-1041 \\ WELINGTON DA COSTA PINHEIRO 2 \\ ORCID: http://orcid.org/0000-0002-6717-2013
}

\begin{abstract}
RESUMO: O objetivo deste estudo é mapear as produções acadêmicas que se dedicaram ao estudo de valores humanos articulados ao contexto educacional e à prática escolar de professores brasileiros. Para tanto, empreendemos o levantamento de teses e dissertações no âmbito dos Programas de PósGraduação em Educação no Brasil, no banco de dados da Plataforma Sucupira, entre os anos de 2013 e 2018, pelo qual compusemos um corpus significativo de 24 produções. Tais achados, após inventariados, foram analisados a partir da metodologia da Análise Temática, como propõem Braun e Clarck (2009), a qual se constituiu como nosso arcabouço epistemológico. Nossos resultados organizam-se em quatro categorias: a) um esforço de conceituação dos valores humanos; b) uma persistente representação dos alunos de escola pública e de áreas periféricas como os principais sujeitos alvo de uma educação em valores humanos; c) uma centralidade no papel da família para uma educação em valores humanos; e d) da proposição religiosa e esportiva como meios eficazes de educação em valores humanos. Disto isto, concluímos que há, nas dissertações e teses publicadas no período de 2013 a 2018 aqui delimitadas, uma conceituação de valores humanos no sentido de valores morais para a formação cidadã de jovens da escola pública. Tal conceituação faz referência, eminentemente, a esses valores como uma alternativa de combate à insegurança, à indisciplina e à violência na realidade destes jovens cuja família é apontada como referência de ausência de modelos de boa conduta. Neste sentido, o papel assumido pela religiosidade e pelo esporte servem como meios e modelos para educá-los em valores humanos.
\end{abstract}

Palavras-chave: Valores humanos; Educação; Juventude.

\section{EDUCATION AND HUMAN VALUES: AN EVALUATION OF STUDIES PRODUCED IN BRAZIL IN 2013-2018}

\begin{abstract}
The objective of this study is to map the academic productions dedicated to the study of human values articulated to the educational context and school practice of Brazilian teachers. To this end, we have undertaken a survey of theses and dissertations within the Post-Graduate Education Programs in Brazil, in the database of the Sucupira Platform, between the years 2013 and 2018, through which we have composed a significant corpus of 24 productions. These findings, after being inventoried, were analyzed from the Thematic Analysis methodology, as proposed by Braun and Clarck
\end{abstract}

${ }^{1}$ Universidade Federal do Pará (UFPA). Belém, PA, Brasil. < liviasousasilva2014@gmail.com>

${ }^{2}$ Universidade Federal do Pará (UFPA). Belém, PA, Brasil.<welingtoncpinheiro@hotmail.com> Educação em Revista|Belo Horizonte |v.36|e234587|2020 
(2009), which was constituted as our epistemological framework. Our results are organized in four categories: a) an effort to conceptualize human values; b) a persistent representation of students from public schools and peripheral areas as the main target subjects of an education in human values; c) a centrality in the role of the family for an education in human values; and d) the religious and sports proposition as effective means of education in human values. That said, we concluded that there is, in the dissertations and thesis published from 2013 to 2018 outlined here, a concept of human values in the sense of moral values for the citizen formation of young people in public school. This concept refers, eminently, to these values as an alternative for combating insecurity, indiscipline and violence in the reality of these young people whose family is pointed out as a reference for the absence of models of good conduct. In this sense, the role assumed by religiosity and sports serve as means and models to educate them in human values.

Keywords: Human values; Education; Youth.

\section{EDUCACIÓN Y VALORES HUMANOS: UNA APRECIACIÓN DE LOS ESTUDIOS PRODUCIDOS EN BRASIL EN LOS AÑOS DE 2013 A 2018}

RESUMEN: El propósito de este estudio es mapear las producciones académicas dedicadas al estudio de los valores humanos vinculados al contexto educativo y a la práctica escolar de profesores brasileños. Para lograrlo, hicimos la búsqueda de tesis de doctorado y de maestríade Programas de Posgrado en Educación en Brasilen el repositorio de la Plataforma Sucupira, entre los años de 2013 a 2018, y fueron encontradas 24 producciones. Estas producciones fueron analizadas mediante Análisis Temático, como proponen Braun y Clarck (2009), que se constituye aquí como marco epistemológico. Los resultados se organizan en cuatro categorías: a) un esfuerzo de conceptualización de los valores humanos; b) una persistente representación de los alumnos de la escuela pública y de zonas periféricas de la ciudad como los principales sujetos objetivos de una educación de valores humanos; c) una centralización en el rol de familia para una educación de valores humanos; d) de la proposición religiosa y deportiva como medios eficaces de educación en valores humanos.Como conclusión, observamos que existen en las tesis de doctorado y de maestría, publicadas entre los años de 2013 a 2018 y aquí presentadas, una conceptualización de valores humanos en el sentido de valores morales para la formación de ciudadanía de los jóvenes de la escuela pública. Esta conceptualización hace referenciación a estos valores como una alternativa de combatir la inseguridad, la indisciplina y la violencia en la realidad de estos jóvenes cuya familia es vista como referencia de ausencia de modelos de buena conducta. En este sentido, el rol asumido por la religiosidad y por el deporte sirven como medios y modelos para educarlos en valores humanos.

Palabras clave: Valores humanos; Educación; Juventud.

\section{INTRODUÇÃO}

Este artigo objetiva mapear os resultados da investigação acerca dos contributos advindos das produções acadêmicas que se dedicaram ao estudo de valores humanos articulados com a educação escolar, no período de 2013 a 2018, a partir do levantamento de teses e dissertações no banco de dados da Plataforma Sucupira.

O estudo em foco parte de inquietações gestadas no contexto educacional contemporâneo, no qual a escola é questionada quanto aos valores que utiliza em suas práticas. Essa e outras indagações 
refletem as transformações sociais que se entrelaçam às práticas implantadas em consequência da estrutura neoliberal no Brasil.

Essas práticas escolares não deixam de estaratravessadas por essa lógica dominante do capital, gerada pelos inúmeros dispositivos ideológicos que influenciam na construção de conhecimentos, de sentimentos e ações na escola, quer sejam por parte dos gestores, dos professores e dos alunos. A tal influência se enlaça a subjetividade desses sujeitos que constroem a escola e fazemque ela seja um território de competições acirradas e violência, o que prejudica, sobremaneira, oprocesso de ensino -aprendizagem, as relações intersubjetivas e a inclusão.

Dessa maneira, a importância dessa investigação sobre as produções acadêmicas que se dedicaram ao estudo de valores humanos articulados com a educação no período de 2013 a 2018, caminha na direção de se pensar e refletir sobre o que esses estudos apontam com base nos resultados de suas investigações.

Consideramos que a construção de uma educação cidadã, deve ser sustentada por valores que possibilitem, principalmente, a formação de alunos para a convivência, para a ressignificação dos modos de vida e de suas relações e para a conquista de espaços sociais. Para Pereira (2002), isso depende não somente da escola, mas também dos resultados das investigações sobre essa temática que em muito podem e devem contribuir para que a educação escolar possa ressignificar suas práticas de forma crítica e, assim, tornar a escola um território que priorize valores que deem suporte à relações mais promissoras, solidárias e humanas.

A partir de tais premissas, perguntamos: o que revelamas produções acadêmicas na perspectiva de dissertações e teses sobre os valores humanos articulados com a educação escolar? Conhecer e problematizar essas relações estabelecidas entre valores humanos e educação traz contribuições importantes à área educacional ao consubstanciar compreensões sobre seus fundamentos, intenções e representações subjacentes a esse campo de produção, assim como para repensar iniciativas futuras de práticas educativas pautadas em valores humanos nas escolas.

Por esse intuito, este artigo orquestra-se em três seções: a primeira traz a Introdução, iniciando-se o diálogo sobre valores humanos, apresenta o objetivo, a problematização da temática valores humanos articulados à educação, bem como a pertinência do estudo para o campo educacional; a segunda apresenta a Análise Temática Braun e Clarck (2009) como opção metodológica do estudo, a descrição dos dados da pesquisa, o processo de constituição da categorização temática e a fundamentação teórica de análise; e por fim, a terceira seção, na qual apresentamos os resultados, as análises e discussões, a partir de quatro categorias temáticas que emergem das teses e dissertações analisadas. 


\section{ARCABOUÇO TEÓRICO-METODOLÓGICO DA PESQUISA}

O estudo caracteriza-se por uma pesquisa qualitativa de cunho bibliográfico, na modalidade Estado do Conhecimento. Este, paraRomanowski e Ens (2006, p. 38), constitui-se em um “[...] mapeamento que desvende e examine o conhecimento já elaborado e aponte os enfoques, e os temas mais pesquisados e as lacunas existentes". Uma iniciativa que, para além de listar produções sobre um mesmo tema, configura-se enquanto um esforço analítico que possa contribuir com a compreensão dos caminhos epistemológicos, as abordagens, os resultados já alcançados, e assim percebermos a relação disposta entre valores humanos e Educação.

\section{Caracterização do corpus da pesquisa}

Utilizamos a plataforma Sucupira para selecionar o corpus desse estudo, cujo recorte éo período de 2013 e 2018. A delimitação temporal foi estabelecida a fim de demarcar o que foi produzido na década na qual o estudo se situa, tendo no ano de 2013 o primeiro registro sobre o tema investigado; enquanto que em 2018 foram identificados os últimosestudos até o momento da realização do levantamento (novembro de 2019). Na condução do levantamento, foram utilizados, de maneira combinada, os seguintes descritores: "valores humanos" e "educação". Na seleção das produções, privilegiamosaquelas que se detinham no ensino de valores humanos em ambientes escolares, ou que abordassem valores humanos e prática docente, o que resultou no achado de 24 trabalhos - 19 dissertações e 5teses. Apresentamos a seguir, no quadro 1, a caracterização do corpus de nosso estudo.

\section{Quadro 1 - Corpus selecionado para o estudo}

\begin{tabular}{|c|c|c|c|c|c|}
\hline $\mathrm{ANO}$ & INSTITUIÇÃO & TÍTULO & TIPO & AUTOR & ÁREA \\
\hline 2013 & $\begin{array}{c}\text { Escola Superior } \\
\text { de Teologia }\end{array}$ & $\begin{array}{l}\text { A prática educativa de valores } \\
\text { humanos universais através do ensino } \\
\text { religioso com crianças e adolescentes } \\
\text { do ensino fundamental }\end{array}$ & Dissertação & $\begin{array}{c}\text { Moises } \\
\text { ManirSarquiz }\end{array}$ & $\begin{array}{l}\text { Ciências } \\
\text { Humanas } \\
\text { (Teologia) }\end{array}$ \\
\hline 2013 & PUC - RS & $\begin{array}{c}\text { Educar crianças pequenas para } \\
\text { valores: uma práxis impregnada de } \\
\text { cuidado }\end{array}$ & Dissertação & $\begin{array}{c}\text { Maria Souza } \\
\text { dos Santos }\end{array}$ & $\begin{array}{l}\text { Ciências } \\
\text { Humanas } \\
\text { (Educação) }\end{array}$ \\
\hline 2013 & UNB & $\begin{array}{l}\text { Os parâmetros curriculares nacionais } \\
\text { e a formação de valores na } \\
\text { concepção dos educadores }\end{array}$ & Dissertação & $\begin{array}{c}\text { Dener } \\
\text { Geraldo } \\
\text { Batista Neves }\end{array}$ & $\begin{array}{l}\text { Ciências } \\
\text { Humanas } \\
\text { (Educação) }\end{array}$ \\
\hline 2013 & UFPB & $\begin{array}{l}\text { Valores humanos e bullying: um } \\
\text { estudo pautado na congruência entre } \\
\text { pais e filhos }\end{array}$ & Dissertação & $\begin{array}{c}\text { Ana Karla } \\
\text { Silva Soares }\end{array}$ & $\begin{array}{l}\text { Ciências } \\
\text { Humanas } \\
\text { (Psicologia) }\end{array}$ \\
\hline 2013 & UFMG & $\begin{array}{l}\text { Formação de valores e atitudes: como } \\
\text { professores do ensino fundamental } \\
\text { enfrentam este desafio }\end{array}$ & Dissertação & $\begin{array}{l}\text { Henrique } \\
\text { Melo Franco } \\
\text { Ribeiro }\end{array}$ & $\begin{array}{l}\text { Ciências } \\
\text { Humanas } \\
\text { (Educação) }\end{array}$ \\
\hline 2014 & PUC - Petrópolis & $\begin{array}{l}\text { Os valores apreendidos pela rede } \\
\text { educativa: o caso da escola paroquial } \\
\text { bom Jesus }\end{array}$ & Dissertação & $\begin{array}{l}\text { Sirlene } \\
\text { Marques } \\
\text { Pereira }\end{array}$ & $\begin{array}{l}\text { Ciências } \\
\text { Humanas } \\
\text { (Educação) }\end{array}$ \\
\hline 2014 & UNB & Identificação e formação de valores & Dissertação & Luiz & Ciências \\
\hline
\end{tabular}




\begin{tabular}{|c|c|c|c|c|c|}
\hline & & $\begin{array}{l}\text { pessoais no ambiente escolar de } \\
\text { ensino fundamental II: o sujeito } \\
\text { ecológico em construção }\end{array}$ & & $\begin{array}{l}\text { Gonzaga } \\
\text { Lapa Junior }\end{array}$ & $\begin{array}{l}\text { Humanas } \\
\text { (Educação) }\end{array}$ \\
\hline 2014 & UFES & $\begin{array}{l}\text { Os sentidos da escola no contexto da } \\
\text { crise de sentido: uma análise a partir } \\
\text { do programa educação em valores } \\
\text { humanos / projeto escola sustentável } \\
\text { em Serra-ES }\end{array}$ & Dissertação & $\begin{array}{l}\text { Luciana } \\
\text { Pimentel } \\
\text { Rhodes } \\
\text { Goncalves }\end{array}$ & $\begin{array}{l}\text { Ciências } \\
\text { Humanas } \\
\text { (Educação) }\end{array}$ \\
\hline 2015 & $\begin{array}{l}\text { Faculdade Unida } \\
\text { de Vitória }\end{array}$ & $\begin{array}{l}\text { Um estudo sobre o ensino religioso: a } \\
\text { relação entre o ensino religioso e a } \\
\text { educação no município de serra e } \\
\text { processo de construção e } \\
\text { aprendizagem dos valores humanos }\end{array}$ & Dissertação & $\begin{array}{l}\text { Isaac Pinto } \\
\text { Da Silva }\end{array}$ & $\begin{array}{l}\text { Ciências } \\
\text { Humanas } \\
\text { (Teologia) }\end{array}$ \\
\hline 2015 & UFES & $\begin{array}{l}\text { O ensino em valores a partir das } \\
\text { maneiras e artes de fazer: } \\
\text { possibilidades pedagógicas para as } \\
\text { aulas de educação física }\end{array}$ & Dissertação & $\begin{array}{l}\text { Thaise } \\
\text { Ramos } \\
\text { Varnier }\end{array}$ & $\begin{array}{l}\text { Ciências da } \\
\text { Saúde } \\
\text { (Educação } \\
\text { Física) } \\
\end{array}$ \\
\hline 2015 & $\begin{array}{l}\text { Universidade } \\
\text { Tiradentes }\end{array}$ & $\begin{array}{l}\text { Educar na pós-modernidade: a } \\
\text { produção de valores a partir da escola } \\
\text { - um estudo no Instituto Federal de } \\
\text { Sergipe }\end{array}$ & Dissertação & $\begin{array}{c}\text { Karen } \\
\text { Gomes Leite }\end{array}$ & $\begin{array}{l}\text { Ciências } \\
\text { Humanas } \\
\text { (Educação) }\end{array}$ \\
\hline 2016 & PUC-RS & $\begin{array}{l}\text { O papel dos valores humanos na } \\
\text { aceitação social em crianças do } \\
\text { ensino fundamental. }\end{array}$ & Dissertação & $\begin{array}{l}\text { Marco } \\
\text { Aurélio } \\
\text { Virgílio }\end{array}$ & $\begin{array}{l}\text { Ciências } \\
\text { Humanas } \\
\text { (Psicologia) }\end{array}$ \\
\hline 2016 & USP & $\begin{array}{c}\text { Os impactos do curso de } \\
\text { especialização em ética, valores e } \\
\text { cidadania nas concepções e prática } \\
\text { profissional dos professores }\end{array}$ & Dissertação & $\begin{array}{l}\text { Custodio } \\
\text { Cruz de } \\
\text { Oliveira E } \\
\text { Silva }\end{array}$ & $\begin{array}{l}\text { Ciências } \\
\text { Humanas } \\
\text { (Educação) }\end{array}$ \\
\hline 2017 & $\begin{array}{l}\text { Universidade de } \\
\text { Sorocaba }\end{array}$ & $\begin{array}{l}\text { O colégio salesiano São José: } \\
\text { juventude, educação e valores }\end{array}$ & Dissertação & $\begin{array}{l}\text { Mauro } \\
\text { Bombo }\end{array}$ & $\begin{array}{l}\text { Ciências } \\
\text { Humanas } \\
\text { (Educação) }\end{array}$ \\
\hline 2017 & $\begin{array}{l}\text { Universidade do } \\
\text { Oeste Paulista }\end{array}$ & $\begin{array}{c}\text { As práticas morais e a aprendizagem } \\
\text { de valores e regras: experiência com } \\
\text { assembleias em uma escola pública de } \\
\text { ensino fundamental }\end{array}$ & Dissertação & $\begin{array}{l}\text { Veronica } \\
\text { Nogueira } \\
\text { Vanni }\end{array}$ & $\begin{array}{l}\text { Ciências } \\
\text { Humanas } \\
\text { (Educação) }\end{array}$ \\
\hline 2017 & $\begin{array}{c}\text { Universidade } \\
\text { Estadual Paulista } \\
\text { Júlio de Mesquita } \\
\text { Filho }\end{array}$ & $\begin{array}{l}\text { Ambiente escolar e valores: um } \\
\text { estudo comparativo entre a escola de } \\
\text { tempo integral e a escola de tempo } \\
\text { parcial no ensino fundamental II }\end{array}$ & Dissertação & $\begin{array}{l}\text { Emerson da } \\
\text { Silva dos } \\
\text { Santos }\end{array}$ & $\begin{array}{l}\text { Ciências } \\
\text { Humanas } \\
\text { (Educação) }\end{array}$ \\
\hline 2017 & $\begin{array}{c}\text { Universidade } \\
\text { Estadual Paulista } \\
\text { Júlio De Mesquita } \\
\text { Filho } \\
\end{array}$ & $\begin{array}{l}\text { Valores morais em alunos do ensino } \\
\text { fundamental II e médio do interior } \\
\text { do estado de São Paulo }\end{array}$ & Dissertação & $\begin{array}{c}\text { Graziella } \\
\text { Diniz Borges }\end{array}$ & $\begin{array}{l}\text { Ciências } \\
\text { Humanas } \\
\text { (Educação) }\end{array}$ \\
\hline 2018 & PUC-RS & $\begin{array}{l}\text { Da inovação em educação às escolas } \\
\text { emergentes: papel social, valores e } \\
\text { estratégias para a formação humana }\end{array}$ & Dissertação & $\begin{array}{c}\text { Diogo } \\
\text { Silveira } \\
\text { Heredia } \\
\text { YAntunes }\end{array}$ & $\begin{array}{l}\text { Ciências } \\
\text { Humanas } \\
\text { (Educação) }\end{array}$ \\
\hline 2018 & USP & $\begin{array}{c}\text { Valores humanos, jogos olímpicos e } \\
\text { envolvimento: uma pesquisa com os } \\
\text { alunos e profissionais de educação } \\
\text { física }\end{array}$ & Dissertação & $\begin{array}{l}\text { Otávio } \\
\text { Augusto } \\
\text { Gratão }\end{array}$ & $\begin{array}{l}\text { Ciências da } \\
\text { Saúde } \\
\text { (Educação } \\
\text { Física) }\end{array}$ \\
\hline 2014 & $\begin{array}{c}\text { Universidade } \\
\text { Est.Paulista Júlio } \\
\text { De Mesquita } \\
\text { Filho/Pr.Prudente }\end{array}$ & $\begin{array}{l}\text { Educação em valores: solução para a } \\
\text { violência e a indisciplina na escola? }\end{array}$ & Tese & $\begin{array}{c}\text { Juliana } \\
\text { Aparecida } \\
\text { Matias Zechi }\end{array}$ & $\begin{array}{l}\text { Ciências } \\
\text { Humanas } \\
\text { (Educação) }\end{array}$ \\
\hline 2014 & UFCE & $\begin{array}{c}\text { Jovens na escola de ensino médio } \\
\text { Wladimir Roriz: construção da } \\
\text { cultura de paz e dos valores } \\
\text { humanos. }\end{array}$ & Tese & $\begin{array}{c}\text { Maria Joyce } \\
\text { Maia Costa } \\
\text { Carneiro }\end{array}$ & $\begin{array}{c}\text { Ciências } \\
\text { Humanas } \\
\text { (Educação) }\end{array}$ \\
\hline
\end{tabular}




\begin{tabular}{|c|c|c|c|c|c|}
\hline 2015 & UNB & $\begin{array}{c}\text { A gestão da educação em valores na } \\
\text { perspectiva da sociabilidade humana } \\
\text { em instituições confessionais } \\
\text { católicas }\end{array}$ & $\begin{array}{c}\text { Tese } \\
\text { Ulmira }\end{array}$ & $\begin{array}{c}\text { Olências } \\
\text { Bernadete } \\
\text { Dassoler }\end{array}$ & $\begin{array}{c}\text { Humanas } \\
\text { (Educação) }\end{array}$ \\
\hline 2017 & USP & $\begin{array}{c}\text { Afetividade, valores e referências } \\
\text { morais: um estudo com jovens } \\
\text { estudantes da rede pública estadual } \\
\text { paulista }\end{array}$ & Tese & $\begin{array}{c}\text { Brigitte } \\
\text { UrsulaStach } \\
\text { Haertel }\end{array}$ & $\begin{array}{c}\text { Ciências } \\
\text { Humanas } \\
\text { (Educação) }\end{array}$ \\
\hline 2017 & $\begin{array}{c}\text { Universidade } \\
\text { Estadual Paulista } \\
\text { Júlio de Mesquita } \\
\text { Filho }\end{array}$ & $\begin{array}{c}\text { Leituras, valores e comportamentos: } \\
\text { práticas escolares no colégio } \\
\text { Tiradentes da polícia militar de } \\
\text { Uberaba-MG }\end{array}$ & Tese & $\begin{array}{c}\text { Anelise } \\
\text { Martinelli } \\
\text { Borges de } \\
\text { Oliveira }\end{array}$ & $\begin{array}{c}\text { Ciências } \\
\text { Humanas } \\
\text { (Educação) }\end{array}$ \\
\hline
\end{tabular}

Fonte: produção própria dos autores.

A amostragem obtida gerou uma média de seis trabalhos por ano, interessados no estudo da articulação entre valores humanos e Educação. Geograficamente, observou-se uma concentração desses estudos na região Centro-Sul do país: Sudeste (15); Sul (4);Centro-Oeste (3), vinte e um (21) trabalhos no total. No Nordeste, encontramos dois (2) trabalhos, e a Região Norte ficou sem representatividade.

No quadro acima, também verificamos que a área deconhecimento na qual se concentram o maior número de produções relacionadas aos valores humanos é Ciências Humanas, distribuídas em: Educação (18); Teologia (2); e Psicologia (2), com destaque para os estudos na Educação que apresenta a maioria de estudos sobre a temática valores humanos no âmbito escolar, contando com: (5) teses e (13) dissertações. Contudo, há estudos na área das Ciências da Saúde, especificamente, na Educação Física, que contabilizou (2) dissertações.

\section{Método de agrupamento das obras}

Utilizamos a Análise Temática para a organização e agrupamento das produções encontradas, seguida da elaboração de temáticas correspondentes a cada agrupamento. Consideramos neste estudo a Análise de Temática enquanto “[...] um método analítico qualitativo (...) flexível para análise de dados qualitativos (...) que busca (...) identificar, analisar e relatar padrões (temas) dentro dos dados”, segundoBraun e Clarcke (2006, p. 2). Essa proposta de análise se desenvolve a partir de seis passos básicos, sobre os quais versaremos a seguir.

O primeiro passo refere-se à familiaridade com os dados, que diz respeito à “[...] leitura e releitura dos dados, apontamento de ideias iniciais" (BRAUN; CLARCKE,2006,p. 90); o segundo passo descreve o processo de codificação, que se relaciona à organização dos dados em grupos significativos; o terceiro passo é a Tematização, pela qual agrupamos os códigos encontrados em temas potenciais, organizando os dados significativos para cada um desses temas em construção; o quarto passo, a construção de um mapa temático, envolve a revisão dos temas potenciais, a respeito da coerência entre 
os códigos agrupados enquanto um tema, e dos temas entre si e sua relação com o todo; e organizando esses temas e seus respectivos códigos em organogramas.

O quinto passo: definir e nomear temas consiste em uma iniciativa que objetiva definir e aprimorar os temas constituídos, a partir do estabelecimento do mapa temático final, ao que Braun e Clarcke (2006, p.96) consideram como identificação da "[...]'essência' do assunto de cada tema (bem como os temas globais), e determinar que aspecto dos dados cada tema captura"; e por fim, o sexto passo - relato da análise temática, que se relaciona com a tarefa da escrita da análise empreendida e seus resultados, pela qual devemos tanto fornecer dados identificáveis com o problema inicial, quanto organizar a apresentação desses dados em uma narrativa argumentativa, coerente e coesa, que dê conta de sustentar o estudo em seu mérito e validade.

A seguir, apresentamos o respectivo Mapa Temático decorrente do agrupamento temático de nosso corpus de pesquisa.

\section{Figura 1 - Mapa Temático}

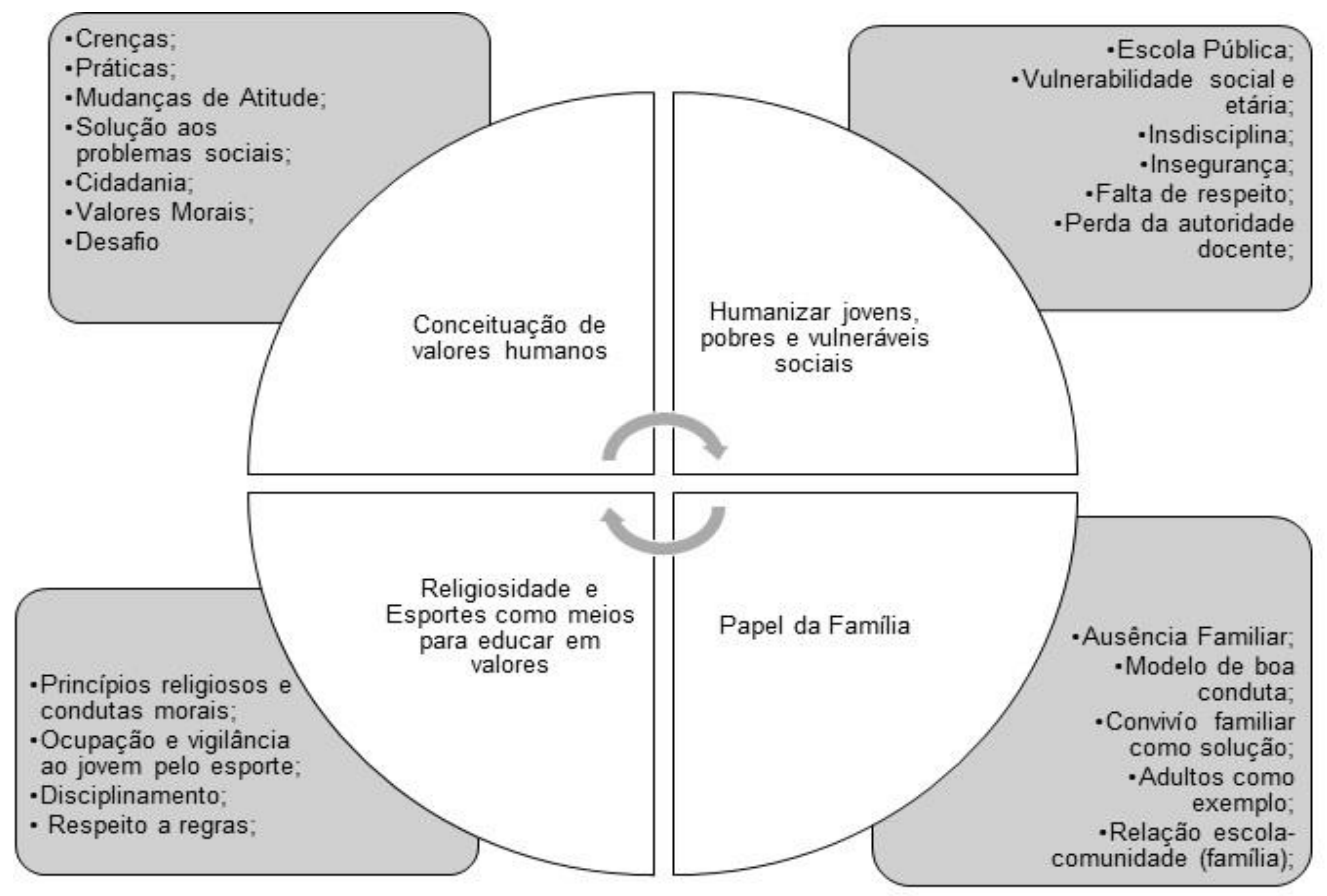

Fonte: produção própria dos autores.

Em síntese e conforme nossa proposição analítica, foi possível apontar grupos significativos de dados que se organizaram em torno de quatro grandes temas: a) Conceituação de valores humanos; b) Valores humanos para humanizar pobres e "vulneráveis"; c) Valores humanos e o papel da família; Religiosidade e esporte como meios para educar em valores humanos. 


\section{Marco teórico de análise do mapa temático}

Para análise e discussão do mapa temático, consideramos os estudos de Gouveia, Martínez e Milfont (2001); Gouveia (2003); Formiga e Gouveia (2005); Gouveia et. al. (2009), que definem uma conceituação e tipologia. Tais estudos conceituam valores humanos enquanto “[...] valores básicos definidos como categorias de orientação que são desejáveis, baseadas nas necessidades humanas e nas pré-condições para satisfazê-las, adotadas por atores sociais, podendo variar em sua magnitude e nos elementos que as constituem" (GOUVEIA, 2003, p.433).

E apresentam uma tipologia de valores humanos conforme suas orientações (pessoais, centrais e sociais), motivadores (humanitário e materialístico) e suas funções (experimentação, realização, existência, supra pessoal, interacional e normativa), como vamos observar no quadro 1 abaixo:

Figura 2 - Definição conceitual dos valores humanos conforme a orientação, subfunções e motivações
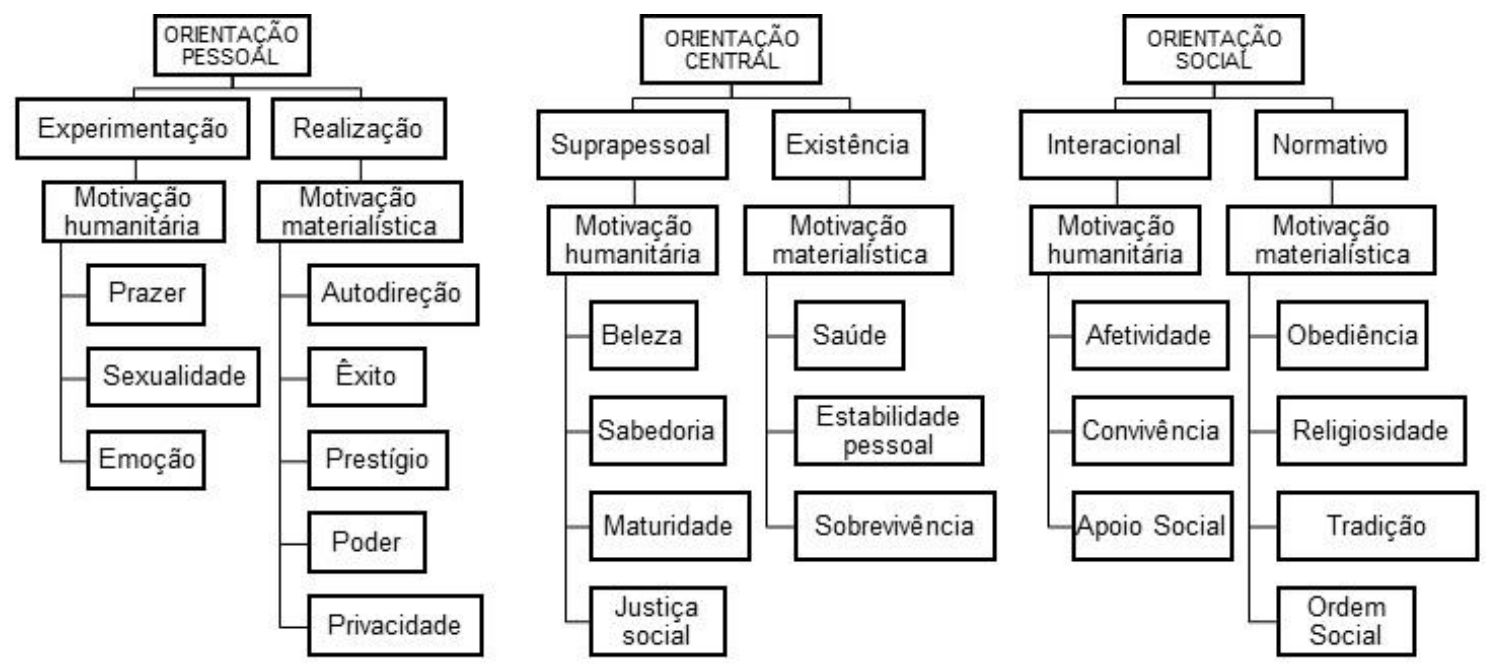

Fonte: produção própria dos autores com base nos estudos de Gouveia, Martínez e Milfont (2001); Gouveia (2003); Formiga e Gouveia (2005); Gouveia et. al. (2009).

Inicialmente, faz-se importante compreender que os valores humanos agrupam-se sob três critérios de orientação, que se subdividem em duas funções psicossociais cada um, a saber: pessoal (experimentação e realização), central (existência e supra pessoal) e social (interacional e normativa) (GOUVEIA, MARTÍNEZ e MILFONT, 2001; GOUVEIA, 2003; FORMIGA e GOUVEIA, 2005; GOUVEIA et. al., 2009).

Valores de orientação pessoal caracterizam-se pela prioridade dos interesses e ganhos próprios, a partir de relações contratuais. Pode-se dizer, dessa forma, que essa orientação pessoal possui um foco intrapessoal. Não podem, por isso, ser confundidos com valores individuais, pois a 
necessidade de satisfazer a si mesmo é uma necessidade humana universal (GOUVEIA, 2003; FORMIGA e GOUVEIA, 2005; GOUVEIA et. al., 2009).

Valores de orientação social correspondem a valores de foco interpessoal, ou seja, sob interesses eminentemente coletivos, e atendem necessidades de interação, pertencimento, afiliação e trocas sociais. Pessoas que assumem esses valores direcionam-se para a convivência com os outros, pois desejam ser considerados, aceitos e integrados a um determinado grupo social, que pode ser a família, amigos, vizinhança etc. Ou, na busca de satisfação de uma necessidade de harmonia entre atores sociais de um determinado contexto social em específico (GOUVEIA, 2003; FORMIGA e GOUVEIA, 2005).

E, por fim, segundo Gouveia (2003) e Formiga e Gouveia (2005), os valores de orientação central que se caracterizam pela tentativa de compatibilizar os valores de orientação pessoal e social, e dessa forma servindo a interesses mistos que consideram tanto o indivíduo quanto a coletividade, isto porque, sua ênfase recai sobre a importância da existência e não da individualidade, embora a existência favoreça a individualidade, quer dizer, atendem às necessidades das pessoas em coletivo.

Vale lembrar que, valores humanos embora universais, não são expressos de maneira isomórfica, quer dizer, do mesmo modo e com a mesma intensidade por todas as pessoas, assim haverá pessoas que irão priorizar valores de orientação pessoal mais que os de orientação social, e vice-versa. E, outras que irão orientar-se pela centralidade e estabelecer prioridades equivalentes entre necessidades pessoais e sociais, sob uma orientação central (GOUVEIA, 2003).

E, que segundo Gouveia (2003) e Formiga e Gouveia (2005), os valores humanos ou valores básicos possuem um fim em si mesmos, ou seja, não podem ser usados como meio ou instrumento para se atingir um objetivo ou metas. Valores se caracterizam como categorias ou princípios-guia voltados à satisfação das necessidades humanas e às condições para que tais necessidades sejam satisfeitas, ou seja, atributos da personalidade humana, que não podem ser ensinados ou aprendidos, porque existem justamente como condição intrínseca ao que caracteriza o humano.

Da mesma forma, os valores humanos se expressam por motivações que pode ser de duas ordens:materialista ou humanitária. Um motivador materialista se expressa por questões pragmáticas, ideias, normas e objetivos práticos, de realizações e ganhos materiais. Diferentemente, um motivador humanitário representa uma motivação idealista, de caráter universal, que não se preocupa em atingir objetivos pragmáticos (GOUVEIA et. al., 2009).

Como podemos observar na figura 2, os valores que representam a subfunção de Experimentação tem orientação pessoal e motivação humanitária. Segundo Gouveia (2003), Formiga e Gouveia (2005) e Gouveia et. al. (2009), pessoas que priorizam tais valores tendem menos a se conformar com regras fixas, status e harmonia, já que a Emoção na qualidade de valor humano 
compõe-se pela busca do desafio, de se viver aventuras excitantes e ou experiências arriscadas. O Prazer que representa nossa necessidade de orgânica de satisfação; e a Sexualidade que provém o prazer sexual. O que favorece inovações e transformações nos cenários de convivência e atuação social.

Valores com subfunção de Realização possuem uma motivação materialístico e também pessoal, pois é a autoestima o princípio que os origina. O Poder refere-se à necessidade de influenciar outras pessoas e ter controle sobre as decisões; Prestígio, atende ao imperativo de ser conhecido e admirado; Exxito, desempenhar atividades com eficiência; Auto direção, que representa pré-condição de liberdade, autossuficiência e autonomia; e Privacidade reconhecimento dos benefícios de ter seu próprio espaço íntimo, o que segundo Gouveia (2003), Formiga e Gouveia (2005) e Gouveia et. al. (2009), colabora com as interações sociais e o funcionamento adequado das instituições, uma vez que indivíduos que dão maior importância a esses valores costumam ser práticos em seus comportamentos e decisões e reconhecem postos hierárquicos baseados na competência pessoal, organização e estrutura social.

Valores de Existência, para Gouveia (2009), funcionam a partir de motivadores materialistas de orientação central, porque servem ao atendimento de necessidades fisiológicas básicas como sono, alimentação e segurança - Sobrevivência, as garantias biopsíquica fundamentais para a manutenção da vida e sobrevivência da pessoa e do meio - Saúde, e garantias de Estabilidade Social, tais como uma vida organizada e planejada. Pessoas que convivem e ou foram formadas em ambientes de escassez ou de ausência dessas garantias básicas, são mais propensas a priorizar valores

Segundo Gouveia (2009), ao contrário do que se poderia pensar, valores como Beleza, Conhecimento e Maturidade não possuem orientações pessoais, mas centrais, porque dizem respeito à própria estabilidade do mundo e sua organização sob estruturas sólidas, de necessidades estéticas e cognitivas. O que da mesma forma representa o valor humano da Justiça Social que é pré-condição de igualdade para satisfação de necessidades. Por isso, pessoas movidas por esses valores possuem motivações humanitárias, pensam de forma mais ampla e suas decisões levam em consideração critérios gerais.

Afetividade, Convivência e Apoio Social são valores com subfunção Interacional, de motivação humanitária com orientações sociais, pois assistem à necessidade humana do destino comum e da experiência de afeto, partilha, pertença e ajuda mútua entre indivíduos, para os momentos difíceis, de acordo com Gouveia (2003) e Gouveia et. al. (2009).

E por fim, valores com subfunção Normativas, pelos quais, segundo os autores (GOUVEIA, 2003; FORMIGA e GOUVEIA, 2005; GOUVEIA et. al., 2009), geralmente, pessoas mais velhas se guiam no atendimento às necessidades de controle e preservação da cultura e normas convencionais, quer sejam institucionais ou sociais. São valores com motivação materialista, porque são 
postos de maneira prática, prescritiva e verticalizada nas relações. Para se ter controle faz-se necessárias relações hierarquizadas, e para isso o valor humano da Obediência é importante, porque se ancora no cumprimento de deveres e obrigações cotidianas, e o respeito a figuras de autoridade: pais, superiores e os mais velhos.

Da mesma forma concorre o valor humano da Religiosidade, pelo reconhecimento da existência de um ser superior e a necessidade de viver uma vida pacífica. O valor da Tradição, como pré-condição de disciplinamento do indivíduo para o convívio coletivo e social, a partir do atendimento de normas sociais de seu país e o respeito às tradições de sua sociedade. E, a Ordem Social, como valor humano que busca a satisfação da necessidade de segurança e proteção da propriedade pública, além da garantia de ordem e segurança nacional, como nos elucida Gouveia (2003), Formiga e Gouveia (2005) e Gouveia et. al. (2009).

\section{OS TEMAS EXPRESSOS NOS ESTUDOS SOBRE VALORES HUMANOS: UMA DISCUSSÃO NECESSÁRIA}

Como nos demonstra nossa análise há basicamente quatro temas significativos advindos dos estudos que se dedicaram a investigar a articulação entre valores humanos e Educação, os quais trataremos a seguir.

Tema 1: Conceituando valores humanos: uma proposição "educativa" normativa de vigilância e disciplinamento como cidadania

Observamos, nos estudos analisados, a preponderância de aportes da Psicologia Social para a sua conceituação de valores humanos, sobretudo, a partir dos contributos da teoria funcionalista dos valores. A qual se representa principalmente pelas contribuições de Valdiney Veloso Gouveia, em diferentes obras citadas na seção anterior

Notamos pela Figura 2 que tais valores podem caracterizar-se por funções de experimentação, realização, existência, supra pessoal, interacional e normativa, sem distinguirem um sujeito específico, uma classe social em especial, nem mesmo uma faixa etária adequada para Educação em valores humanos.

A despeito disso, nosso corpus traduz um conceito próprio de valores humanos, que se afasta em muito do que propõe Gouveia (2009) e a teoria funcionalista; apontando valores enquanto Crenças, Práticas e Atitudes; formação para a Cidadania (cidadania aparece com a mesma intensidade que o valor econômico); como tentativa de responder aos problemas sociais comumente enfrentados pelos jovens; valores morais; educação em valores para mudança de atitudes; valores atitudinais e de prática cidadã; mudanças significativas no comportamento dos filhos; relações menos conflituosas e 
agressivas no interior da escola; promotor de uma Cultura de Paz; respeito, solidariedade, generosidade, tolerância, aceitação da diversidade.

Dessa forma, tais estudos acabam por constituir um modelo de compreensão de valores humanos que o toma por: mudanças de comportamento de jovens alunos; adaptação a regras préestabelecidas e sobre como se comportar em sociedade; além de educação cidadã sob uma compreensão muito neoliberal de cidadania. O nosso corpus toma o aluno jovem, da escola pública e de bairro periférico como destituído desses mesmos valores, e por isso, destituído de cidadania e civilidade.

Por que partir de um conceito de valor humano que o toma como atributo da constituição da pessoa em favor de suas necessidades humanas, para depois propor valores como comportamentos a serem ensinados a jovens? Por que essa faixa etária é privilegiada como alvo de intenções e ações de educação em valores humanos? Por que somente alunos da escola pública?

Primeiramente iremos refletir com Cassab (2012), que a categoria juventude sofre com uma concepção histórica que a considerada tanto pela transição quanto pelo perigo, ou seja, "[...] um momento a ser vigiado e controlado pela ordem adulta" (CASSAB, 2012 pp. 147,148), e assim se justificam os "benefícios de se controlar e reprimir os prazeres da juventude em prol de temperar o caráter", ao "direcionar para ações e espaços mais adequados os impulsos juvenis".

Cassab (2012) também nos mostra que sempre existiram distinções de abordagem educacional no que diz respeito à juventude pobre/operária e a juventude burguesa. Embora ambas fossem vigiadas e controladas, a natureza do controle diferenciava-se conforme a classe social do jovem.

Para a classe abastada, a escola passa a ser a instituição com papel de formação para o “tornar-se adulto”, um lugar de contenção dos impulsos juvenis, um instrumento social de disciplina e controle de transgressões morais, capaz de moldar comportamentos apropriados à manutenção do regime burguês capitalista crescente, para o qual importa o individualismo no preparo para o futuro, a partir dos estudos, conforme Cassab (2012).

Diferentemente, aos filhos dos trabalhadores era reservado precocemente a inserção nas atividades produtivas do trabalho fabril, que de maneira ainda mais incisiva iriam lhes ensinar a obediência e a renúncia. Já que para além da ideia de imaturidade biológica e psicossocial, o jovem pobre também é reconhecido como uma potencial ameaça (CASSAB, 2012). Assim, a sua contenção dos impulsos, controle, vigilância e disciplinamento davam-se por meio do trabalho.

Essa associação entre pobreza, juventude e criminalidade se radicaliza, segundo Cassab (2012), principalmente a partir do movimento higienista no Brasil. Posto que o discurso médico e 
científico da época3 partia de uma visão e entendimento sobre a juventude que conjugava atributos biológicos e psicológicos, quer dizer, sob a associação entre mudanças hormonais e físicas típicas desse período, relacionando-as às características psíquicas próprias da juventude: a rebeldia, o desinteresse, a crise etc. E da mesma forma associou a pobreza e o pobre a toda ordem de desvios e doenças o que, consequentemente, tornou o jovem pobre demarcado pela instabilidade, comportamento agressivo e ou violento - o delinquente.

Para Cassab (2012), foi a própria ciência que corroborou para essa representação de juventude e de jovem pobre. O que da mesma forma Scisleski et. al. (2012, p. 22) advertem ao problematizar " [...] as racionalidades que produzem, sustentam e legitimam a juventude como marginal”. Uma ciência que, dessa forma, se coloca muito mais a serviço do incremento da exclusão, do isolamento, da justificação do poder adulto de submeter esses jovens à vigilância, disciplinamento e punição.

Assim, educação em valores humanos se transmuta na utilização da escola em controle de adultos sobre a geração jovem, sob uma lógica determinista, segregacionista e conservadora, porque educar em valores está relacionadoà disciplina, controle e negação do outro enquanto potencialidade, sujeito de valor e com valores, bem como na prática e reconhecimento do outro como cidadão ou não.

Observamos que valores humanos se assumem também como análogo à cidadania. Não em seu sentido lato, como: "[...] as maneiras de abordar dinâmicas de inclusão e exclusão, de entender o que é considerado direito e/ou responsabilidade de um indivíduo na sociedade" (GIRON, 2012, p. 24). Ao contrário, a partir da tradição neoliberal que se apropria desse conceito para se referir tanto às expectativas quanto à normatividade que deve reger as relações entre indivíduos e o Estado-nação.

Dessa forma, em uma sociedade onde a Educação está pautada sob a égide de relações fundamentadas por imperativos meramente econômicos, "a concepção de sociedade e de cidadania que vem à tona é aquela que prima pela ética utilitarista, pelo individualismo, pela exclusão e pela competitividade"; e, o papel da escola passa a ser moldar o indivíduo desejável e útil a manutenção dessa mesma lógica - mão de obra sob controle, disciplinada e resignada, nos assevera (GIRON, 2012, p.24). O que nos ajuda a compreender o porquêdesses estudos sobre valores humanos articulados à educação privilegiarem a abordagem de valores apenas com função normativa.

Dentre as representações de valores humanos observadas nos estudos analisados, os valores de obediência, religiosidade, tradição e ordem social são os únicos apontados por esses estudos que, podem ser considerados como valores humanos pela teoria funcionalista, da maneira como nos

\footnotetext{
${ }^{3}$ Movimento Higienista - considerado uma corrente de pensamento e ou um projeto de intervenção social gestado na e pela modernidade que se implanta no Brasil nos fins do século XIX e início do século, que tinha como objetivo de educar a população em hábitos de civilidade - padrões de saúde, urbanização, saneamento e higiene social. Para o qual a Educação cumpria papel fundamental de incutir tal ideário por meio da formação dos mais jovens (SOUSA; ARAUJO, 2016). 
esclareceos autores (GOUVEIA, 2003; FORMIGA e GOUVEIA, 2005; GOUVEIA et. al., 2009). Dessa forma, observamos ainda que,apesar dos valores de obediência, religiosidade, tradição e ordem social, virem à tona nesses trabalhos investigados, tais valores vêm subvertidoscomo sinônimo de "cidadania",mas de um sentido de cidadania que se pressupõe enquanto manutenção das relações verticais entre adultos/jovens, de mando/obediência e reverência à figuras de poder na escola e na sociedade.

Assim, podemos compreender, porque se propõemsempreuma educação em valores humanos apenas para jovens pobres das escolas públicas. O que se discutirá melhor a seguir.

\section{Tema 2: Valores humanos para os bárbaros: porque os ricos já nascem cidadãos!}

Observamos que a construção acadêmica acerca de uma educação em valores humanos centra atenção, sobretudo, em temas como: o contexto da escola pública, e ou em contextos sociogeográficos demarcados por vulnerabilidades sociais - as periferias das cidades. Ademais, o sujeito alvo de intenções e ações no âmbito de uma formação em valores humanos é exclusivamente o aluno dessa mesma escola, constituído a partir desse ambiente de "risco" - casa/escola/bairro - que assim, se vê desprovido de valores, e como vetor de indisciplina na escola, violência e de questionamento à “autoridade”4 do professor, conforme os estudos em análise.

Perguntamo-nos: será que centralizar a educação em valores humanos na figura do aluno não pressupõe que adultos possuam valores e crianças e jovens não? Será que não corroboramos com o imaginário da pobreza como fonte de todas as vicissitudes experimentadas em sociedade - doenças, atraso, incivilidade e violência? Não estaríamos, como cientistas, reafirmando estereótipos de exclusão, alinhavando o ato violento diretamente à classe social, à juventude pobre e ao esmaecimento de valores e de comportamentos cidadãos?

Cassab (2012) já assinalava a construção histórica de uma representação de juventude, sobretudo, a pobre, que se constituiu sob uma narrativa demarcada pela hierarquia entre adultos e jovens, uma vez que sempre coube aos adultos a vigilância, o controle e a formação disciplinar desse segmento etário, o que explica a ideia,ainda hoje, corrente de que adultos se encontram municiados de valores humanos e os jovens e crianças não, já que estão em transição para a maturidade. Concorrente a isso, percebemos a abordagem prioritária de valores cuja função é de normatividade, os quais mais uma vez se apresentam pela desigualdade de condições valorativas entre adultos e jovens, da

\footnotetext{
${ }^{4}$ Coloca-se "autoridade" entre aspas nesse contexto por acreditarmos que quando se busca a obediência dos alunos, a relação não se pauta na autoridade e sim no poder, ou no autoritarismo. Já que compreendemos autoridade assim como nos propõe Arendt (1985, p.19) enquanto "o reconhecimento sem discussões por aqueles que são solicitados a obedecer; nem a coerção, nem a persuasão são necessárias. Para que se possa conservar a autoridade é necessário o respeito pela pessoa ou pelo cargo".
} 
necessidade de obediência para a manutenção da ordem social e,assim, da própria autoridade adulta, como nos aponta Gouveia et.al. (2009).

De outra forma, Oliveira e Rosa (2010) demonstram-nos o predomínio de estudos e análises localizados nos territórios da pobreza, em detrimento da reflexão acerca de episódios de violência protagonizados por jovens de classe sociais privilegiadas, como se esses não existissem.

A esse respeito, Fialho (2010) discorre sobre um imaginário constituído, historicamente, entre virtudes - pessoas de bem - e riquezas (proprietários e atividade intelectual em detrimento de atividades manuais) e seu contrário - o não-cidadão, os bárbaros, pessoas a quem a prática da virtude é desconhecida.

Fialho (2010) acredita que tenhamos assimilado muitos dos princípios gregos, tanto em nossa legislação, quanto em nossos conceitos modernos de Estado e República. Assim, nosso ideário republicano subscreveu-se sob cenários materiais e mentais pelos quais os discursos do civilizar-se compreendiam o estabelecimento de uma cidade ideal, planejada e saneada. Um saneamento social, que marginalizou a pobreza e mendicância dos centros urbanos para as periferias, iniciativas voltadas à satisfação dos interesses da elite burguesa e do avanço do capital, o que foi sustentado por muitos "homens de letras da Belém da borracha que viveram na condição de intelectuais do tempo do Progresso e da Civilização" (COELHO, 2011 p. 153).

As questões que se impõe dramaticamente nesse cenário compreendem ao fato de que não nos vemos a todos nós como cidadãos, e de que reificamos 5 criminalidade e violência enquanto jovenspobres. Estereótipos tecidos na generalidade das áreas de periferia. Cuja redenção oferecida pelo Estado/Sociedade seria a escola, pela qual esses sujeitos podem vir a ser "úteis a sociedade reconhecidos cidadãos". Nesse contexto, a escola propõe-se como uma espécie de possibilidade de ascensão entre castas sociais, desde que os "bárbaros" aceitem os códigos de comportamento impostos - formação em valores.

Saviani (1996), em seu texto "valores e objetivos na educação", ajuda-nos a problematizar e desconstruir tais discursos, ao tratar da importância da escola como promotora do homem (e da mulher)6, não só pela proposição de bons valores, mas da observação das pessoas como pessoas com valor.

Nesse sentido, Scisleski et. al. (2012, p. 23) nos convidam a refletir sobre “[...] os jogos de verdade e as relações de poder que constroem esse objeto como natural e verdadeiro, passando a fixar determinadas identidades para esses jovens [...]”. Para que não venhamos a colaborar para a fabricação

\footnotetext{
5 Reificação: conceito herdeiro do pensamento marxista, difundido principalmente por Georg Lukács. "A reificação pressupõe que nós nem percebamos mais nas outras pessoas as suas características que as tornam propriamente exemplares do gênero humano: tratar alguém como uma "coisa" significa justamente tomá-la(o) como "algo", despido de quaisquer características ou habilidades humanas" (HONNETH, 2008, p. 70).

${ }^{6}$ Inserção das autoras em complementaridade necessária ao pensamento de Saviani (1996). Educação em Revista|Belo Horizonte |v.36|e234587|2020
} 
de um sujeito social a quem temer e a quem excluir - o jovem pobre de periferia, apoiando-nos em paradigmas cientificistas.

Acerca do nosso papel como cientistas e a produção de estereótipos, poder-se-ia dizer, baseado nas asserções de Ricoeur (1994), que as teses e dissertações analisadas têm revelado um modelo de análise nomotético, porque partem basicamente de duas premissas, quais sejam: a) a descrição de condições prevalecentes e; b) uma regularidade qualquer, que tomam por uma hipótese universal, empiricamente verificável e que se impõe por lei. É dessa formaque percebemos passar a serem explicados por leis os acontecimentos violentos e os problemas do contexto escolar e social.

Questionamos, assim, se nesses trabalhos analisados, as perguntas direcionadas à realidade não orientam o tipo de achados e aspecto da explicação empreendida?

Porque acreditamos, como nos explica Ricoeur (1994, p.163), que tais explicações possam achar-se viciadas de três modos diferentes, quais sejam, de que "[...] os enunciados empíricos estabelecendo as condições iniciais podem ser falhos; as generalidades alegadas podem não ser leis autênticas; e que a ligação lógica entre premissas e consequência pode ser viciada por um sofisma ou erro de raciocínio".

Que possamos refletir sobre as relações de regularidade, leis, e causalidades até então estabelecidas, que hoje tomam como lei o emprego da pobreza e as vulnerabilidades sociais para explicara ocorrência do fenômeno da violência e outros problemas sociais e educacionais. Eleva-se o jovem-pobre-de periferia como único protagonista possível para atos violentos, e transforma-se a violência em uma característica intrínseca a uma classe social, naturalizando, assim, a relação pobreza como causa, a violência como consequência e o jovem pobre como vetor disseminador.

\section{Tema 3: Valores humanos e o papel da família}

Se tomarmos os problemas sociais por problemas relacionados à juventude, e os problemas da escola como originários tão somente na figura do aluno; uma relação prevista seria a responsabilização da família tanto no que diz respeito à produção de sujeitos desviantes do modelo de "cidadania", quanto como parte imprescindível na solução possível de correção desses comportamentos.

Dessa forma, os estudos analisados trazem à tona temas como a responsabilidade dos pais na formação dos filhos; da criança e o convívio familiar; afastamento da família em relação à escola e relegando às unidades escolares a função de cuidar e educar; e dos adultos - pais - que deveriam servir de exemplo de bons valores, mas que não o são, pois acabam sendo representados pelo signo da "desestrutura". 
Anteriormente, vimos que a generalidade por lei imprimia uma relação direta e determinista entre violência e classe social, ou lugar sociogeográfico de origem - o bairro periférico. Uma outra generalização por lei, criada para justificar a origem da violência na pobreza, seria o estabelecimento de uma relação linear entre o aluno da escola pública que vem de periferia esuasfamílias que são sempre desestruturadas. A falta de virtudes (cidadania), em decorrência da falta de riquezas,tornariam as famílias deterministicamente "desestruturadas". Scisleski et. al. (2012) evidenciam justamente esse persistente modo de leitura dos problemas sociais, que responsabiliza o próprio jovem e sua família, por sua condição de marginalidade. Enquanto o quadro das desigualdades e injustiças sociais não se vê se quer considerado.

Nesse sentido, percebemos que a ideia de uma boa educação e de responsabilização familiar perpassa intimamente: a) presença na escola; b) sistemas disciplinares; e c) práticas punitivas.

As famílias de alunos de escolas públicas são sempre representadas pela ausência, isto é, que não acompanham o desenvolvimento escolar dos filhos.Polônia e Dessen (2005) explicam que há barreiras culturais que colaboram para essa representação familiar, como “[...] a crença de que os pais de nível socioeconômico mais baixos não estão preocupados com seus filhos, adotando frequentemente uma postura negligente e pouco participativa", além de, "acharem que os pais têm pouco ou quase nada a contribuir para o currículo escolar, devendo apenas participar das reuniões para entrega de boletins" (POLÔNIA; DESSEN, 2005 p. 309).

De outra forma, a responsabilidade da família e de sua parceria com a escola recai sob o signo do disciplinamento dos filhos. O que nos impõe uma questão fundamental, que diz respeito à relação entre a instituição do regime democrático e a destituição do poder escolar de infringir punições físicas e ou psicológicas. Vimos com Cassab (2012) que no advento republicano, que foi implementado a partir de um golpe militar, a escola passou a substituir a família em seu papel educativo, porque se estabelecia como uma instituição de controle, normatização e disciplinamento, muito mais eficaz que a instituição familiar. São as proibições legais de punições, que fazem com que a escola comece a questionar novamente as famílias em seu papel "formativo".

Passa-se a chamar a essa impossibilidade de punir física e psicologicamente como "perda de autoridade" e, por conseguinte, os cenários de crise socioeducacional se impõe, já que as famílias hoje também não podem mais usar de violência para educar, o que em boa medida também caracteriza essas famílias como “desestruturadas”, como pontua Pescarolo e Moraes (2016).

Isto quer dizer que, o consenso sobre as práticas disciplinares, o papel da escola, dos professores e da educação em nossa sociedade hoje, estão em contradição com os "novos" princípios democráticos que situam a criança e o adolescente como cidadãos em igualdade de direitos (BRASIL, 2019; BRASIL, 2017). Ao contrário de reconhecerem que as relações entre professor-aluno exigem 
novos comportamentos, novos olhares e fazeres, continua-se a desejar configurações tradicionais de escola e prática docente, que tomavam o valor e a importância do professor acima dos demais, sobretudo, dos alunos.

Arendt (2005), nesse sentido, aponta-nos que o ensino pressupõe competência - conhecer e saber ensinar, e a autoridade pressupõe responsabilizar-se pelo mundo. Se há crise na autoridade docente, esta se relacionaria com esses processos de desresponsabilização do professor e da escola, como instituições somente de ensino e não educativas (ARENDT, 2005).

Por isso, precisamos hoje nos perguntar e refletir de maneira profunda e fundamentada no que se constitui o papel social da educação escolar e do professor, para que não o esvaziemos de sentido, reduzindo-os a mero aparelhamento do Estado para manutenção de regimes de exclusão, disciplinamento e da ordem vigente.

\section{Tema 4: Meios para educar em valores humanos: religiosidade e esportes}

No que diz respeito às ações de implementação e ou propostas didático-pedagógicas de educação em valores humanos, o conjunto de trabalhos em análise, aponta como meios mais eficientes a abordagem da tradução da religiosidade em atitudes práticas; religiosidade e Ensino Religioso como meio de educar em valores humanos; dar ocupação para os sujeitos jovens e vigilância, no que colabora a prática de esportes e valores olímpicos.

Os estudos acadêmicos apostam na vivência da religiosidade como meio para desenvolver comportamentos éticos, morais e de justiça. E na própria disciplina Ensino Religioso como meio privilegiado de educação em valores. Se tomarmos o quadro de valores e suas funções apontadas por Gouveia et. al. (2009), iremos perceber que até aqui o foco tem sido apenas a educação em valores normativos: Obediência, Religiosidade, Tradição e Religiosidade, como já apresentamos anteriormente.

Isso explica o porquê de centrarmos atenção nos jovens, pois se em nossa compreensão de educação em valores humanos perpassa apenas a educação de valores normativos, isto implica ser a figura do jovem, o sujeito social potencialmente tendenciado a questionar as regras e tradições. De acordo com Rocha (2006), a juventude sempre esteve associada à desordem, à contestação dos valores e parâmetros sociais vigentes, não só como um choque de gerações, mas também em certos contextos históricos como choque entre realidades estabelecidas.

Nessa mesma direção, Rocha (2006) reflete sobre a visão de jovem que se ancora na confusão determinista da associação direta entre juventude e problema. Diz-nos a autora que "[...] é como se a juventude estivesse sempre se contrapondo à sociedade adulta", porque "trazem um ar de revolução e questionamentos para o status quo" adulto (ROCHA, 2006 p. 4). 
Por que considerar a religiosidade como um meio de educar em valores humanos? Faz-se importante demarcar que alguns autores apontam distinções entre religião e religiosidade. Deis Siqueira (2013) atribui à religiosidade um caráter subjetivo e ou pessoal, e à religião um caráter institucionalizado - sobre o que se vivencia nas igrejas, centros etc. Nas asserções de Gouveia (2009) e sobre o que se apresenta nos trabalhos analisados, religiosidade representa uma normatividade em função de que a crença em Deus propõe comportamentos determinados em sociedade, ou seja, nos impõe uma norma, ou conduta moral, calcada em valores judaico-cristãos.

Diferentes autores vêm pautando a religião com função de sistema normativo. Kant (2008), por exemplo, atribuiu à crença em Deus a motivação para resistirmos às más inclinações, para nos mantermos em boas condutas morais. Cuja síntese dessa moralidade residiria nos mandamentos. Durkheim (2000), da mesma forma, toma a religião enquanto um sistema de representação coletivo constituinte da vida social moderadora de relações, ou seja, como reguladora da integração entre sujeito e sociedade, uma vez que impõe, crenças, valores e normas.

Está-se propondo educar em valores humanos a partir da religiosidade, com o intuito de educar para valores, principalmente, judaico-cristãos. E, dessa forma, incorremos no erro de generalizar a crença em Deus, e nos valores de determinadas "igrejas" e religiões em detrimento de outras crenças. A respeito disto, Cunha (2016) nos relembra que pressões do campo religioso-católico, a partir da Conferência Nacional dos Bispos do Brasil (CNBB), foram direcionadas pelo segmento católico, cujas propostas incidiram sobre a política educacional para a oferta do Ensino Religioso como disciplina nas escolas públicas.

E, que essa matéria é sobremaneira objeto de muitas disputas, quer seja entre católicos e o avanço das Igrejas Evangélicas, dos não cristãos e dos "sem religião". Segundo Cunha (2016, p.269), há “[...] reações à presença religiosa da educação pública emergem de dentro e de fora do aparelho de Estado". Dessa forma, há tanto quem defenda a sua exclusão enquanto disciplina da LDB, quanto os que defendem sua permanência, mas, ministrada em modalidade não confessional; e os que a defendem de maneira confessional, isto é, aderindo a uma ou outra religião específica. O fato é que hoje o ensino religioso compõe tanto o texto da LDB, quanto o da Base Nacional Comum Curricular.

Uma outra forma de proposição para o desenvolvimento de valores humanos pela educação de alunos jovens, está relacionada à prática de esportes, quer seja pela tradução dos valores olímpicos como valor humano, quer seja como ocupação para os sujeitos jovens e sua vigilância. Os estudos que suscitam o esporte como meio de educar em valores, focam, sobretudo, em uma "ética esportiva" que se ancora nos valores olímpicos - amizade, respeito e excelência; em uma vida ativa e saudável; na busca por excelência; e responsabilidade social. Apreciações que se assumem pela representação da Educação Física como veículo de formação moral. 
Korsakas e Júnior (2002) afirmam o inegável potencial educativo do esporte, contudo, chamam atenção para que tipo de educação pretendemos desenvolver a partir dos esporte, uma vez que diferentes modalidades esportivas podem ter objetivos diversos e perspectivas pedagógicas inclusive contraditórias, como é o caso da prática de esportes de rendimentos ou seja, aqueles que visam o alcance de resultados; ou a prática de esportes para o desenvolvimento integral, e que evitem a seletividade e hipercompetitividade; ambas modalidades que constam na Lei no 9.615 de 19987.

Os autores classificam assim, pelo menos duas formas de educar pelo esporte: a) uma pedagogia do rendimento, que acredita estar presente em diferentes contextos sociais, na escola e no dia-a-dia das pessoas, sob a obrigatoriedade de prevalecer sobre os outros, de se tornar melhor que o adversário, um valor que depois se revela em outros momentos da relação em sociedade,como na competição por uma vaga de trabalho, por destaque na atividade laboral, por melhores salários, no "rankeamento" de alunos desde tenra idade conforme seu rendimento escolar, no Enem etc. Educar nesse sentido assume-se pela exclusão dos "menos habilidosos" (KORSAKAS; JUNIOR, 2002).

A pedagogia do rendimento não se restringe à prática do esporte, mas parece estar presente no dia-a-dia das pessoas que se submetem e são submetidas à obrigatoriedade de render, de ser o melhor em qualquer situação: ser o primeiro na lista de aprovados do vestibular, o profissional com melhor remuneração, o melhor aluno, etc. Diferentemente, “[...] a prática esportiva deve-se desenvolver ancorada pelos princípios da totalidade, coeducação, emancipação, participação, cooperação" (KORSAKAS; JUNIOR, 2002, p.90).

Dessa forma, propor o esporte como valor para educação de jovens, pode assumir duas perspectivas: uma visando à formação integral, colaborativa e de humanização; outra acirrando um ethos competitivo, de superação do outro e de exclusão dos "mais fracos" e "menos habilidosos" na técnica das modalidades esportivas. Bracht (2000) denomina essa primeira forma como o esporte da escola, que é adaptado e modificado para fins educativos, inclusivos e coletivos; a segunda como o esporte na escola, aquele que é transportado diretamente para o contexto escolar tal qual se manifesta, hegemonicamente, na sociedade, contribuindo, assim, para a vivência de uma prática com princípios do alto rendimento, que segrega e privilegia os mais aptos em determinada modalidade esportiva.

\section{CONCLUSÕES E CONSIDERAÇÕES FINAIS}

Nossas conclusões apontam para uma construção científica que serve de respaldo para justificar o controle e disciplinamento do jovem pobre, representado como potencialmente perigoso, para a manutenção da ordem e estabilidade social, a partir de propostas didático-pedagógicas que a

\footnotetext{
${ }^{7}$ A Lei no 9.615 de 1998 que dispõe sobre a Política Nacional do Esporte (KORSAKAS; JUNIOR, 2002).
} Educação em Revista|Belo Horizonte |v.36|e234587|2020 
despeito da superação dos contextos de crise, violência, e ou de vulnerabilidade, visam o ensino de valores normativos: obediência, tradição, ordem social e religiosidade.

Este é o momento do texto em que não teceremos Considerações Finais, pois o nosso desejo e objetivo é suscitar um ato contínuo de problematização das interseções entre a Educação e os Valores Humanos. Compreender como o campo acadêmico tem abordado essa questão e os conhecimentos produzidos são apenas um primeiro passo frente à necessidade premente de refletirmos acerca de determinadas questões nessa seara, tais como:

O que hoje tomamos por valores humanos?

Se a vulnerabilidade social, a violência, e as injustiças sociais exigem uma educação em valores humanos, por que educamos as vítimas e não os algozes?

Há um investimento de educação em valores ou de adestramento moral, e controle sobre a população mais pobre?

Qual o objetivo de uma sociedade que "educa" crianças e jovens da escola pública em pretensos valores humanos de - obediência, disciplina e virtudes religiosas?

Esse não é o momento de terminarmos! Mas de começarmos a nos questionar em nossas próprias condutas, sobre o nosso modo de pensar. É preciso agora, e a partir de então, refletir criticamente sobre a relação entre problemas e soluções, entre vítimas e opressores, e redefinir o quadro das prioridades e público-alvo das iniciativas e políticas de educação em valores humanos.

Não seriam os grandes empresários, os banqueiros, os grandes proprietários de terras, e boa parte dos políticos que nos "representam", os principais responsáveis pela produção e manutenção das desigualdades sociais e econômicas? Não seriam esses segmentos os mais necessitados de uma educação em valores humanos? Educar em valores somente as pessoas da periferia não contribui para a culpabilização do próprio pobre pela sua condição de pobreza e vulnerabilidade?

Vamos adentrar um pouco mais nos questionamentos e suscitar a quase total invisibilidade da escolar particular. Não estariam lá sendo formados futuros dirigentes? Lá também não estudam filhos de pais ausentes? Crianças e jovens experimentando os mais diversos transtornos psíquicos e de aprendizagem em decorrência dessa desestrutura familiar? Por acaso aos que são ricos não é necessário educar em valores? Eles nascem sabendo como serem humanos e cidadãos? Como exercer o poder, como lidar com a liberdade e o prazer? Porque humanizar o aluno criança/jovem da escola pública e periférica, e não considerar a criança/jovem dos segmentos abastados?

Ademais, faz-se necessário problematizar a própria constituição de trabalhos acadêmicocientíficos e sua implicação ética. Quando elegemos um segmento social de análise e um campo de pesquisa devemos refletir sobre as consequências de nossas pesquisas para a vida de pessoas reais. 
Devemos, da mesma forma, atentar para análises parciais e de viés ideológico excludente que vamos reafirmando por pura irreflexão.

\section{REFERÊNCIAS}

ARENDT, Hannah. A crise na educação. In: Entre o passado e o futuro.

Tradução Mauro W. Barbosa de Almeida. São Paulo: Perspectiva, 2005.

ARENDT, Hannah. Da Violência. Tradução de Maria Drummond Trindade. Brasília: Ed. UnB, 1985.

BRACHT, Valter. Esporte na escola e esporte de rendimento, Movimento, Porto Alegre, RS, v.6 n ${ }^{\circ}$ 12, p. 14-24, 2000. Disponível em: http://seer.ufrgs.br/Movimento/article/viewFile/2504/1148 Acesso em: 30 de setembro de 2019.

BRAUN, Virgínia.; CLARKE, Victória. Usando análise temática em psicologia, QualitativeResearch in Psychology, [S.1], v.3 n. 2, p. 77-101, 2006. Disponível em: http:/ / eprints.uwe.ac.uk/11735 http://dx.doi.org/10.1191/1478088706qp063oa. Acesso em: 25 de agosto de 2019.

BRASIL. Constituição da República Federativa do Brasil [recurso eletrônico]. — Brasília: Supremo Tribunal Federal, Secretaria de Documentação, 2019. Disponível em: https://www.stf.jus.br/arquivo/cms/legislacaoConstituicao/anexo/CF.pdf. Acesso em: 17 de novembro de 2019.

BRASIL. Estatuto da criança e do adolescente. - Brasília: Senado Federal, Coordenação de Edições Técnicas, 2017. Disponível em: https://www2.senado.leg.br/bdsf/bitstream/handle/id/534718/eca_1ed.pdf?sequence=1. Acesso em: 17 de novembro de 2019.

CASSAB, Clarice. Contribuição à construção das categorias jovem e juventude: uma introdução. Locus: revista de história. Juiz de Fora, MG, v. 17, nº 2, p. 145-159, 2012. Disponível em: http://www.uff.br/nugea/files/2010/09/Locus.pdf. Acesso em: 26 Jan., 2018.

COELHO, Geraldo Mártires. Na Belém da belle époque da borracha (1890-

1010): dirigindo os olhares. Escritos (Fundação Casa de Rui Barbosa), [S.l], v. 5, n5, p. 141-168, 2011. Disponível em: http://www.casaruibarbosa.gov.br/escritos/numero05/FCRB_Escritos_5_8_Geraldo_Ma rtires_Coelho.pdf. Acesso em: 26 Jan., 2018.

CUNHA, Luiz Antônio. A entronização do ensino religioso na base nacional curricular comum. Educ. Soc., Campinas, v. 37, n. 134, p.266-284, jan.-mar., 2016. Disponível em: http://www.scielo.br/pdf/es/v37n134/1678-4626-es-37-134-00266.pdf. Acesso em: 02 de outubro de 19.

DURKHEIM, Émile. As Formas Elementares da Vida Religiosa. São Paulo: Martins Fontes, 2000.

FIALHO, Maria do Céu. Rituais de cidadania na Grécia Antiga. In: LEÃO, Delfim Ferreira; FERREIRA, José Ribeiro; FIALHO, Maria do Céu. Cidadania e Paideia na Grécia Antiga. Coimbra: Imprensa da Universidade de Coimbra, 2010, p. 111-144. 
FORMIGA, Nilton Soares; GOUVEIA, Valdiney. Valores humanos e condutas anti-sociais e delitivas. Psicologia: Teoria e Prática. São Paulo, SP, v. 7, no 2, p. 134-170, dez. 2005. Disponível em: http://pepsic.bvsalud.org/scielo.php?script=sci_arttext\&pid=S1516-36872005000200006. Acesso em: 17 de novembro de 2019.

GIRON, Graziela Rossetto. Políticas públicas, educação e neoliberalismo: o que isso tem a ver com cidadania? Revista de Educação PUC-Campinas, Campinas, SP, v. 1, n. 24, abr. 2012. Disponível em: <http://periodicos.puc-campinas.edu.br/seer/index.php/reveducacao/article/view/109/97>. Acesso em: 19 set. 2019.

GOUVEIA, Valdiney V. A natureza motivacional dos valores humanos: evidências acerca de uma nova tipologia. Estudos de Psicologia. [s/1], v. 8, n. 3, p. 431-443, 2003. Disponível em: http://www.scielo.br/pdf/epsic/v8n3/19965.pdf. Acesso em: 17 de novembro de 2019.

GOUVEIA, Valdiney V.. et al . Teoria funcionalista dos valores humanos: aplicações para organizações. RAM, Rev. Adm. Mackenzie (Online). São Paulo, v. 10, n. 3, p. 34-59, Jun. 2009. Disponível em: <http:/ /www.scielo.br/scielo.php?script=sci_arttext\&pid=S167869712009000300004\&lng=en\&nrm=iso >. Acesso em: 02 de outubro de 2019.

GOUVEIA, Valdiney V.; MARTÍNEZ, Eva; MILFONT, Maja Meira Taciano Lemos. A estrutura e o conteúdo universais dos valores humanos: análise fatorial confirmatória da tipologia de Schwartz.

Estudos de Psicologia. Natal, v. 6, n. 2, p. 133-142, 2001. Disponível em:

http://www.scielo.br/scielo.php?pid=S1413-294X2001000200002\&script=sci_abstract\&tlng=pt. Acesso em: 17 de novembro de 2019.

HONNETH, Axel. Observações sobre a reificação. Civitas - Revista de Ciências Sociais, v. 8, n.1, p. 68-79, janeiro-abril, 2008.

Disponível em: https://www.redalyc.org/pdf/742/74211531005.pdf. Acesso em: 17 de novembro de 2019.

KANT, Immanuel. A religião nos limites da própria razão. Covilhã: Lusosofia, 2008. Disponível em: http://www.lusosofia.net/textos/kant_immanuel_religiao_limites_simples_razao.pdf. Acesso em: 02 de outubro de 2019.

KORSAKAS, Paula; DE ROSE JUNIOR, Dante. Os encontros e desencontros entre esporte e educação: uma discussão filosófico-pedagógica. Revista Mackenzie de Educação Física e Esporte, São Paulo, v. 1, n. 1, p. 83-93, 2002.

Disponível em: http://editorarevistas.mackenzie.br/index.php/remef/article/view/1354/1057. Acesso em: 30 de setembro de 2019.

OLIVEIRA, Maristhela Bergamim de; ROSA, Edinete Maria. Juventude, violência e alteridade. Temas psicol., Ribeirão Preto, v. 18, n. 1, p. 113-121, 2010. Disponível em

$<$ http://pepsic.bvsalud.org/scielo.php?script=sci_arttextepid=S1413389X2010000100010elng=ptenr $\mathrm{m}=\mathrm{iso}>$. Acesso em: 24 Jan. 2018.

PEREIRA.Rita Maria Ribes. Tudo ao mesmo tempo agora: Considerações sobre a infância no presente. In: GONDRA, José.(org) História, Infância e escolarização. Rio de Janeiro: 7 Letras, 2002, p. 149167. 
PESCAROLO, Joyce Kelly; MORAES, Pedro Rodolfo Bodê de. O declínio da autoridade docente na escola contemporânea. Revista Diálogos Educacionais. Curitiba, v. 16, n. 47, p. 147-168, Jan./Abr. 2016. Disponível em:

https://periodicos.pucpr.br/index.php/dialogoeducacional/article/view/1999/1903. Acesso em: 24 Jan. 2018.

POLÔNIA, Ana da Costa; DESSEN, Maria Auxiliadora. Em busca de uma compreensão das relações entre família e escola. Psicologia Escolar e Educacional. Campinas, v. 9, n. 2, p. 303-312, dez., 2005. Disponível em:

<http://www.scielo.br/scielo.php?script=sci_arttextepid=S141385572005000200012elng=enenrm=is o>. Acesso em 24 Jan. 2018.

RICOEUR, Paul. Tempo e Narrativa: Tomo I. São Paulo: Papirus, 1994.

ROCHA, Maria Cristina. Juventude: apostando no presente. Imaginário, São Paulo, v.

12, n. 12, p. 205-223, Jun., 2006. Disponível em

$<$ http://pepsic.bvsalud.org/scielo.php?script=sci_arttextepid=S1413666X2006000100011 elng=ptenr $\mathrm{m}=$ iso $>$. acessos em 24 jan., 2018.

ROMANOWSKI, Joana Paulin; ENS, Romilda Teodora. As pesquisas denominadas do tipo "estado da arte" em educação. Revista Diálogo Educacional, [S.l.], v. 6, n. 19, p. 37-50, jul. 2006. Disponível em: < https://periodicos.pucpr.br/index.php/dialogoeducacional/article/view/24176>. Acesso em: 25 ago. 2019.

SAVIANI, Demerval. Valores e objetivos na educação. In: SAVIANE, Demerval. Educação: do senso comum à consciência filosófica. 11 ed. Campinas: Autores Associados, 1996, p. 35-39.

SCISLESKI, Andrea Cristina Coelho et al . Juventude e pobreza: a construção de sujeitos potencialmente perigosos. Arq. bras. psicol., Rio de Janeiro, v. 64, n. 3, p. 19-34, dez. 2012. Disponível em <http://pepsic.bvsalud.org/scielo.php?script=sci_arttext\&pid=S1809-

$52672012000300003 \& \operatorname{lng}=$ pt\&nrm=iso $>$. Acesso em: 17 de novembro de 2019.

SIQUEIRA, Deis. Religião e religiosidade: indivíduo e sociedade.Revista Estudos de Sociologia. Araraquara, SP v. 18, n. 34, p. 117-134, jan-jun, 2013.

Disponível em:https://periodicos.fclar.unesp.br/estudos/article/view/5296. Acesso em: 02 de outubro de 2019

SOUSA, Marlucy do Socorro Aragão de; ARAÚJO, Sônia Maria da Silva. José Veríssimo e o projeto de educação nacional sobre a influência do higienismo. História Actual Online. [S.1.] v. 39, n.1, p. 105114, 2016.nDisponível em:

https://webcache.googleusercontent.com/search?q=cache:dgEiWrj9dnMJ:https://dialnet.unirioja.es/d escarga/articulo/5411296.pdf $+\& \mathrm{~cd}=1 \& \mathrm{hl}=\mathrm{pt}-\mathrm{BR} \& \mathrm{ct}=\mathrm{clnk} \& \mathrm{gl}=\mathrm{br}$. Acesso em: 17 de novembro de 2019. 